PAWEŁ SZUPPE

Wydział Teologiczny UKSW

e-mail:ppp-1975@o2.pl

DOI: http://dx.doi.org/10.18290/rped.2019.11.1-11

\title{
SYLWETKI UCZONYCH I NAUCZYCIELI
}

Nauczyciel (ang. teacher, fr. maître, professeur, niem. Lehrer, ros. uczitiel) - osoba ucząca innych przez przekazywanie określonych treści, wprowadzająca w świat wartości oraz kształtująca kompetencje i umiejętności potrzebne w życiu. To profesjonalista, przygotowany merytorycznie, pedagogicznie, psychologicznie, metodycznie. Stanowi źródło wiedzy, moralności, doświadczenia społecznego i życiowego w zmieniającym się świecie. Wyzwala aktywność uczących się, wspomaga ich rozwój. Jego działalność jest skierowana na kulturę przyszłości i budowanie właściwych relacji międzyludzkich. Powodzenie tego procesu zależy od kilku czynników: osobowości nauczyciela; kompetencji i motywacji do pracy dydaktyczno-wychowawczej, programów edukacji; warunków szkolnych; postaw uczniów i rodziców; zewnętrznych sytuacji społecznych.

Na przełomie XIX i XX w., szczególnie zaś w okresie dwudziestolecia międzywojennego, nauczyciele polscy pełnili różne misje: społeczne, kulturowe, narodowe. Przekazywali ideały oraz wzorce moralne, uczyli pracy, walki o byt narodowy i niepodległość. Cieszyli się dużym zaufaniem społecznym, ale ich status zawodowy i materialny pozostawiały wiele do życzenia.

Nauczyciel pełni ważną, brzemienną w skutki rolę społeczną. Jego dawny prestiż traci dziś na znaczeniu. Być dobrym, kreatywnym, efektywnym, pełnym pasji nauczycielem nie jest łatwo w czasach nieustannych zmian we wszystkich obszarach rzeczywistości i w życiu człowieka.

Problematyka dotycząca osobowości nauczycieli zajmuje istotne miejsce w myśli pedeutologicznej. Wyrazem tego są liczne publikacje. W kontekst ten wpisuje się książka Nauczyciele. Szkice portretów uczonych i nauczycieli. Pozycja ta jest szczególnie ważna, ponieważ ukazuje sylwetki polskich profesorów, pedagogów, wychowawców działających w trudnych warunkach historycznych, jakim był okres dwudziestolecia międzywojennego oraz w czasach współczesnych. Mimo trudnej sytuacji, przekazywali wiedzę i wartości, uczyli szacunku dla drugiego człowieka.

Recenzowana publikacja prezentuje sylwetki profesorów i nauczycieli w ich działalności na różnych - nie tylko akademickich czy szkolnych - płaszczyznach. Mieli oni znaczący wkład w tworzeniu teorii subdyscyplin pedagogicznych. Zasłużyli się też dla praktyki edukacyjnej. Analiza ich dorobku pozwala na wyciągnięcie wniosku, że najlepsze wyniki osiągali pedagodzy, którzy łączyli podejście teoretyczne z praktycznym. Znajo- 
mość realiów edukacyjnych stanowiła fundament dla tworzenia koncepcji, teorii, narzędzi do dalszej pracy. Autorzy artykułów przedstawiają sylwetki pedagogów z przeszłości, tych, którzy nie tylko bezpośrednio oddziaływali na uczniów szkoły, gdzie pracowali, ale też w szeroko rozumianej kulturze, jako twórcy zmian edukacyjnych i uczestnicy przełomowych wydarzeń w historii edukacji.

Książka składa się z dwóch chronologicznie ułożonych części. Pierwsza ukazuje profesorów, służących nauce i edukacji akademickiej. Otwiera ją tekst, prezentujący etos zawodu nauczyciela akademickiego z perspektywy czasu (Edward Walewander). Kolejne artykuły przedstawiają sylwetki twórców nauk o wychowaniu i działaczy edukacyjnych: Ludwikę Jeleńską, zajmującą się wychowaniem i edukacją dzieci w wieku przedszkolnym i wczesnoszkolnym (Barbara Surma); Aleksandra Manczarskiego, pedagoga działającego na rzecz osób z wadą słuchu (Iwona Czarnecka); ks. Wincentego Granata, kapłana, nauczyciela akademickiego, rektora Katolickiego Uniwersytetu Lubelskiego, propagatora personalistycznego humanizmu (Eugeniusz Sakowicz); Marię Danilewicz-Zielińską, pisarkę, tłumaczkę, historyka literatury i wychowania (Andrzej Meissner); Stefana Kunowskiego, pedagoga i teoretyka wychowania katolickiego (Alina Rynio); Stanisława Michalskiego, historyka wychowania drugiej połowy XX w. i nauczyciela akademickiego (Wiesław Jamrożek). Część tę zamykają teksty poświęcone: pedagogom zajmującym się ochroną przyrody w Drugiej Rzeczypospolitej oraz edukacją przyrodniczą (Edyta Wolter); badaniom nad dziejami opieki społecznej (Wiesław Partyka); Halinie Sali-Wójcik, arteterapeutce oddziałującej wychowawczo na swoich podopiecznych przez sztukę (Andrzej Jasnos).

Druga część publikacji omawia pedagogów służących szkole i społeczeństwu. Znajdują się w niej teksty prezentujące nauczycieli, którzy wyróżniali się aktywnością edukacyjną, społeczną i kulturalną od średniowiecza po czasy współczesne. Z lektury tej części pracy poznajemy: działalność naukową i twórczość średniowiecznego mnicha Hrabana Maura (Krzysztof Ratajczak); nauczycieli-jezuitów pracujących w Kolegium Poznańskim, wychowawców wielu pokoleń młodzieży (Michał Nowicki); Antoniego Andrzejowskiego, nauczyciela Gimnazjum i Liceum Wołyńskiego w Krzemieńcu (Katarzyna Buczek); Karola Miarkę, pedagoga, pisarza, wydawcę, działacza społecznego Górnego Śląska i Śląska Cieszyńskiego (Danuta Kocurek); Aleksandra Piątkiewicza SJ, opiekuna sceny szkolnej w konwikcie chyrowskim (Małgorzata Puchowska); sytuację nauczycieli na Kresach oraz ich pracę w trudnych warunkach (Hanna Markiewiczowa); Ignacego Ziębowicza, nauczyciela i działacza społecznego w środowisku wiejskim (Piotr Gołdyn); s. Melchiory Porożyńskiej, wybitnej nauczycielki i zasłużonej dyrektorki szkoły (Agnieszka Skrzypek); ks. Stanisława Hałko, organizatora polskiego szkolnictwa w Białymstoku oraz Jakuba Szapiro, esperantysty z tego miasta (Agnieszka Suplicka).

Prezentowane dzieło jest cenną publikacją naukową, napisaną przystępnym językiem. Należy też dodać, że każdy artykuł zawiera bogatą bibliografię, umożliwiającą pogłębienie tematyki podjętej przez poszczególnych Autorów. Książkę warto polecić pedagogom, historykom oraz wszystkim, którzy zajmują się dziejami teorii wychowania i edukacji. 